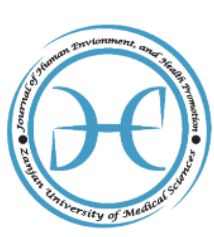

Journal of Human, Environment and Health Promotion

\author{
Journal homepage: www.zums.ac.ir/jhehp
}

\title{
The Status of Electronic Waste in Iran
}

\author{
Seyedeh Monireh Mirgerami a, ${ }^{*}$ \\ Abbas Ali Zamani a iD \\ a Department of Environmental Sciences, School of Science, University of Zanjan, Iran. \\ ${ }^{b}$ Department of Chemistry, School of Science, University of Zanjan, Iran.
}

*Corresponding author: Seyedeh Monireh Mirgerami

Department of Environmental Sciences, School of Science, University of Zanjan, Iran, 4513933844. Tell: +98- 9197496641.

E-mail address: monirehgerami@yahoo.com

\section{A R T I C L E I N F O}

Article type:

Original article

\section{Article history:}

Received January 4, 2018

Revised February 19, 2018

Accepted February 24, 2018

DOI: $10.29252 /$ jhehp.4.2.3

\section{Keywords:}

E-waste

Iran

Management

Status

\begin{abstract}
A B S T R A C T
Background: The present study aimed to estimate the flow of electronic waste (e-waste) in Iran in order to establish a baseline for these toxic, potentially valuable wastes.

Methods: Questionnaires were prepared to determine the amount of waste produced by households, institutions, repair centers, and importers and sellers of electronic products. In total, 22 electronic products (e-products) were tracked and classified into several categories, including computers, televisions, batteries, CD/DVDs, computer peripherals, telephones, multimedia players, and recorders. The questionnaires were completed in Tehran, Mashhad, Sanandaj, and Zanjan cities, Iran. In total, 860 questionnaires were completed via face-toface interviews. The results were generalized to the entire country so as to estimate the level of e-waste.

Results: In 2012, the amount of e-waste in Iran was 288,000 tons, which was estimated to reach 444 million tons by 2032 . This translates to an estimated annual e-waste per capita of 5.37 kilograms, which is lower than the current global value (7.2 kilograms). In addition, the findings indicated that technological innovation and market expansion accelerate the replacement of equipment, thereby significantly increasing e-waste.

Conclusion: According to the results, the management of e-waste requires proper infrastructures to avert a crisis in e-waste management in Iran.
\end{abstract}

\section{Introduction}

In the 1990s, computer products started to enter households in Iran where the magnitude and flow of e-waste generation is not well known. Only do a few studies exist in Iran which contain a rough estimation of the installed base of computers and e-waste generated. The purpose of this study is to estimate electronic wastes (e-wastes) flow in Iran, for the first time, to establish a baseline of knowledge about such potentially valuable and toxic wastes.

E-waste comprises of electronic products (e-products), such as broken or obsolete televisions, computer monitors, central processing units (CPUs), and landline and cellular telephones. With the rapid development of the electronic industry, use of e-products has become commonplace in the residential, institutional, organizational, and business sectors [1]. Furthermore, rapid technological advances have led to the reduced cost of powerful machines, contributing to shorter lifespan and frequent replacement of e-products. E-products quickly lose their resale value; nevertheless, consumers continue to store outdated electronics believing that they are of value. According to a study by the National Safety Council Environmental Health Center (1999), three-quarters of all the computers that are sold in the United States remain stockpiled in a garage, closet, or storage space, and eventually end up in landfills [2]. 
Discarded electrical and electronic products are the fastest growing waste streams; it has been estimated that they constitute $8 \%$ of municipal wastes [3]. The rapid growth in this segment of waste is of great concern due to hazardous and toxic contents, such as cadmium, mercury, and lead [4].

Approximately $70 \%$ of the heavy metals, mercury, and cadmium in the landfills of the United States come from ewaste. In addition, consumer electronics account for $40 \%$ of the lead found in landfills. These toxins have been reported to cause various health problems, including brain damage, allergic reactions, and cancer [5]. In this regard, batteries containing mercury and rechargeable batteries containing cadmium, lead, and lithium are considered to be a significant environmental concern [6].

The volume, weight, storage needs, and cost of e-waste management pose different challenges regarding solid waste or household hazardous waste. Many countries have proposed and implemented strategies to deal with these challenging wastes [7].

Waste electrical and electronic equipment (WEEE) is a source of copper, aluminum, and gold. When these resources are not recovered, raw materials must be mined and processed in order to develop new products, which leads to the significant loss of resources and environmental damage due to mining, manufacturing, transport, and energy use [8-10]. The adverse health and environmental consequences of the improper handling and treatment of WEEE have increased the concerns regarding its management [11].

Greenpeace International (2005) has estimated that 20-50 million tons of WEEE is discarded globally each year, with Asian countries disposing of almost 12 million tons [12]. In addition, the WEEE generated per capita in the European Union (EU) was reported to be 4-20 kilograms annually before May 2004 [3]. There are uncertainties regarding the definition of this issue. Electro-scrap is the fastest growing waste stream in the EU, which is rising at the rate of 3-5\% per year [13].

In Iran, Abdoli and Daryabeighi (2005) predicted that by 2021, Iranians will have consumed about 85 million computers and generated approximately 7.83 million tons of computer e-waste [14]. In Ahvaz city, 9,000 tons of e-waste was produced in 2011, and the WEEE per capita was estimated at nine kilograms [15]]. E-waste in Iran includes domestically produced and discarded e-products. A limited portion of e-wastes, mostly batteries, is imported and should be factored into future e-waste management. In this respect, Zoeteman has reported that 1,000 tons of WEEE has been illegally transported from the Netherlands, $10 \%$ of which was destined for the Middle East and North Africa (Egypt, Jordan, Iran, and Turkey) [16]. Table 1 shows the indicators of ewaste development in Iran.

According to the information in Table 1, the population growth is linear, while information and communication technology (ICT) users have grown exponentially in Iran.
The present study aimed to provide a reliable overview of the amount of the e-waste generated in Iran. The results could be used by government agencies in implementing e-waste management and environmental compliance programs through enforcement agencies, recycling coordinators, solid waste facilities, and hazardous waste programs.

Table 1: Development indicators for Iran with bearing on e-waste. Source: (World-bank) [15]

\begin{tabular}{lccc}
\hline Indicators & $\mathbf{2 0 0 1}$ & $\mathbf{2 0 0 6}$ & $\mathbf{2 0 1 0}$ \\
\hline Population & $66,313,553$ & $70,582,086$ & $73,973,630$ \\
Population growth Annual \% & 1 & 1 & 1 \\
Telephone Lines & $10,896,572$ & $22,626,944$ & $26,848,900$ \\
Telephone lines per 100 & - & 32 & - \\
$\begin{array}{l}\text { Internet users per 100 } \\
\text { Cellular phone subscription }\end{array}$ & $2,087,353$ & $15,385,289$ & $54,051,764$ \\
$\begin{array}{l}\text { Cellular phone subscription } \\
\text { per 100 }\end{array}$ & 3 & 22 & 73 \\
$\begin{array}{l}\text { Landline broadband internet } \\
\text { subscribers }\end{array}$ & 661 & 100,000 & 962,250 \\
$\begin{array}{l}\text { Landline broadband internet } \\
\text { subscribers per 100 }\end{array}$ & 0 & 0 & 1 \\
Population covered by cellular & 32 & 82 & -
\end{tabular}

phone network \%

Urban household population

with personal computer (PC) *

$6,900,000$

-Means data not available.

${ }^{\star}$ According to Statistical Center of Iran, 2010.

\section{Materials and Methods}

Questionnaires were distributed in four cities located in the northern regions of Iran as part of a baseline study. There were no historical data on e-product sales, storage, waste, recycling, and lifespan. The questionnaires were focused on residential and institutional sectors, as well as the importers, sellers, and repairers of e-products. The present study was performed based on the E-waste Assessment Methodology Training and Reference Manual and adapted to local conditions [18]. In total, 860 questionnaires were completed in Tehran, Mashhad, Zanjan, and Sanandaj cities, located in the northern regions of Iran.

To analyze the statistical data SPSS software (version 18) was used. Within the software three statistical tests were used including (ANOVA) Analysis of variance (two-way parametric analysis of variance), Kruskal-Wallis (one-way non-parametric analysis of variance) and Post Hoc Test (compare means of groups that have been determined to have some overall statistically significant differences). After the collection and classification of data, they were analyzed in each separate city and then statistical data of different cities were compared. Then, to estimate the waste level in Iran, results were generalized to the whole country. Tables and relevant charts were provided using Excel software (version 2013).

The household sector in each city was divided into three zones of high, medium, and low in terms of income status, and 50 questionnaires were completed in each zone (total: 150 per city/town, overall: 600). Moreover, 60 questionnaires were completed in the institutional sectors of Zanjan and Mashhad. Sales data of the retailers and wholesalers of e-products were collected using 25 questionnaires in each city, and 100 
questionnaires were completed by the repairers of electronics in the selected areas. After the collection and classification of the data using SPSS version 18, they were analyzed for each city, and the data of different cities were compared using the Excel software. The estimated values were generalized to the entire country based on the calculated e-waste generated per head. Approximately $22 \%$ of 54 million urban citizens in Iran live in the selected areas.

In the current research, 22 e-products were tracked and categorized based on the five categories (total: 10 categories) of the EU Directive (2012) [19]. The categories that were not covered in the study included large household appliances (e.g., refrigerators, washing machines), small household appliances, lighting equipment, medical devices, and automatic dispensers. In addition, rechargeable, nonrechargeable, and automobile batteries and CD/DVDs were tracked in this study, which are not included in the EU Directive.

The tracked products included personal computer (PC) components (e.g., CPU, mouse, monitor, and keyboard), laptops printers, scanners, copiers, projectors, fax machines, landline and cellular telephones, radios, televisions (e.g., cathode ray tube [CRT], LCD/LED/plasma flat screens), video and audio cameras and recorders, multimedia players, hand-held video game consoles, and other electronic equipment (e.g., stereos, amplifiers, battery-operated electronic tools and toys, sporting equipment with electronic components, and equipment for the collection, storage, processing, presentation or communication of information by electronic means). These products were selected since they represent the majority of the e-products used in Iran and have been the focus of electronic recycling initiatives in other countries as well. The analysis in the present study covered the products used in the main economic sectors (residential, commercial, and institutional).

Estimation of the e-waste flow is a complex task. The first step in our research was estimating the e-waste generation since the WEEE/e-waste inventory is the basis of every disposal/treatment strategy. There are five methods that are commonly used to develop an e-waste inventory, each of which the material flows that are described below [3, 20, 21]:

1. Market supply method utilizes past domestic sales data in addition to the average lifespan of the products in a specific region.

2. Consumption and use method extrapolates the average amount of electronic equipment in a typical household.

3. Carnegie Mellon method, which is a variation of the market supply method and calculates WEEE based on the sales data, assumptions about the typical lifespan of e-products, recycling, landfills, and storage. The assumptions are countryspecific products, demand for the proper knowledge of consumer behaviors, and disposal.
4. Saturated market method, which assumes that for each newly purchased appliance, one reaches the end of its lifespan.

5. Time-step method, which calculates WEEE based on private and industrial stock and sales data.

In the current research, we used the combination of methods 1-3. Methods one and two require the assumptions about the average lifespan of e-products and their average weight to derive the e-waste generation per ton, and method three requires the stockpiling data. The data used for the calculations in this study belonged to 2012 .

\section{Results and Discussion}

\subsection{Product Lifecycle}

There were no available frameworks to estimate the lifecycle of e-products. The framework proposed in the present study primarily relies on the patterns of product use and consumption, which begin at the time of purchasing the product and end with its disposition. It is notable that such lifecycle of e-products to e-waste does not consider nonexistent collection and recycling processes.

The first phase of product lifecycle begins with its purchaser or first user. The second phase is where the product may be given or sold to another individual for reuse, storage (e.g., in a closet or basement) or undergoing a combination of reuse and storage. The electronic devices that are not a candidate for resale are disposed of as waste. In Iran, most of the e-wastes that are directly disposed into landfills are CD/DVDs and batteries, which are not considered valuable. The second phase may also involve the transfer of a product from one individual to another as a gift or by sale without a third party, such as electronics recyclers, metal scrapers or collectors.

The third phase of product lifecycle is when the last user removes the product from a private home or business due to the desire to replace, stop using or stop storing the product. At this point, the product is ready for end-of-life (EOL) management and is transferred to a third party (e.g., a secondhand dealer or collector) or is disposed of. Once the product is in the hands of a second-hand dealer, it may be sold for reuse. In the fourth phase, valuable materials (e.g., copper and plastics) are recovered (mostly through open burning as informal recycling) and are used to make new products. The residuals of the fourth phase are disposed of in a landfill.

\subsection{Product Lifespan}

The lifespan of a product is the time between its initial purchase and the time when it is ready for EOL management/disposal. Product lifespan is considered to be a major factor for this methodology. The lifespan of an eproduct must be known in order to determine the quantity of the ensuing e-waste for subsection 3.5. The total lifespan of a particular product encompasses several stages of use. Since the lifespan may vary in different products, unique lifespan 
assumptions have been made for each product type. For instance, televisions are typically kept longer than computers. It is assumed that there are no differences in the lifespan of the products from residential, commercial, and institutional sectors. In the present study, the lifespan of each product was calculated using Equation 1, as follows:
$\mathrm{T}=\overline{\mathrm{T}}_{\mathrm{f}}+\overline{\mathrm{T}}_{\mathrm{s}}$

where $\mathrm{T}$ is the lifespan, $\overline{\mathrm{T}}_{\mathrm{f}}$ represents the mean duration of usage (year), and $\overline{\mathrm{T}}_{\mathrm{s}}$ shows the mean duration of storage (year). To calculate the lifespan of an e-product, data on its usage and years in storage were collected from residential and institutional sectors using questionnaires (Table 2).

Table 2: E-product per capita and total in the studied cities and whole country

\begin{tabular}{|c|c|c|c|c|c|c|}
\hline \multirow[t]{2}{*}{ E-product } & \multicolumn{5}{|c|}{ E-product per capita in households } & \multirow{2}{*}{$\begin{array}{c}\text { Total e-products in Households \& Institutions } \\
\text { Iran }\end{array}$} \\
\hline & Tehran & Mashhad & Zanjan & Sanandaj & Iran & \\
\hline Fax machine & 0.05 & 0.01 & 0.01 & 0.03 & 0.03 & $3,144,282$ \\
\hline Landline phone & 0.51 & 0.52 & 0.43 & 0.41 & 0.47 & $45,264,312$ \\
\hline Printer & 0.06 & 0.04 & 0.07 & 0.06 & 0.06 & $9,406,590$ \\
\hline Scanner & 0.03 & 0.02 & 0.04 & 0.04 & 0.03 & $3,828,609$ \\
\hline Photocopier & 0.03 & 0.01 & 0.00 & 0.02 & 0.01 & $1,441,212$ \\
\hline Laptop & 0.18 & 0.12 & 0.16 & 0.17 & 0.16 & $12,276,454$ \\
\hline PC & 0.18 & 0.17 & 0.16 & 0.18 & 0.17 & $33,175,227$ \\
\hline $\begin{array}{l}\text { Flat screen } \\
\text { monitor }\end{array}$ & 0.10 & 0.10 & 0.10 & 0.11 & 0.10 & $18,491,862$ \\
\hline CRT monitor & 0.09 & 0.08 & 0.07 & 0.09 & 0.08 & $15,191,257$ \\
\hline Multimedia player & 1.01 & 0.85 & 0.87 & 0.81 & 0.89 & $47,515,295$ \\
\hline CRT TV & 0.26 & 0.24 & 0.25 & 0.19 & 0.24 & $12,691,790$ \\
\hline Flat screen TV & 0.19 & 0.17 & 0.14 & 0.19 & 0.17 & $9,178,945$ \\
\hline CD/DVD & 55.71 & 53.24 & 48.74 & 28.05 & 46.44 & $2,491,086,092$ \\
\hline Camera & 0.27 & 0.29 & 0.30 & 0.23 & 0.27 & $14,718,811$ \\
\hline Game Console & 0.10 & 0.09 & 0.06 & 0.09 & 0.09 & $4,642,648$ \\
\hline $\begin{array}{l}\text { Projector } \\
\text { Rechargeable }\end{array}$ & 0.00 & 0.00 & 0.01 & 0.01 & 0.00 & 137,895 \\
\hline $\begin{array}{l}\text { Battery } \\
\text { Non-rechargeable }\end{array}$ & 2.00 & 1.86 & 2.13 & 1.73 & 1.93 & $103,550,785$ \\
\hline Battery & 5.19 & 3.93 & 6.25 & 3.53 & 4.73 & $253,487,366$ \\
\hline Car battery & 0.30 & 0.31 & 0.25 & 0.22 & 0.27 & $14,401,162$ \\
\hline Radio & 0.19 & 0.20 & 0.19 & 0.18 & 0.19 & $10,232,619$ \\
\hline
\end{tabular}

According to the obtained results, radios had the longest duration of use, whereas cell phones had the shortest duration of use although they tend to be stored longer than they are used. Flat screen televisions are new products and have a low average duration of storage. To calculate the lifespan of the eproducts with no storage stage (e.g., CD/DVDs and batteries), we applied the mean data from other countries [22]. Moreover, the lifespan of mouse devices and keyboards were assumed to be five years (Table 3). The lifespan of e-products in Iran is similar to those in China [23], with the exception of flat screen televisions, which have gained popularity in Iran only recently.

\subsection{Quantities of E-products}

E-products were quantified for each of the selected cities in the household and institutional sectors, and the e-products per capita were determined and generalized to the entire country. The number of mouse devices and keyboards was considered to be equal to the number of PCs. There were 20,510,025 governmental and non-governmental employees in the institutional sector in Iran in 2010 (latest data available). In addition, there were 2,065,982 government employees, which comprised $10 \%$ of total employees. Equation 2 was used to estimate the number of the e-products in this sector, as follows:

$\mathrm{N}_{\mathrm{ee}}=\overline{\mathrm{N}}_{\mathrm{pc}} \times \mathrm{P}+\mathrm{N}_{\mathrm{ei}}$
Where $\mathrm{N}_{\mathrm{ee}}$ denotes the total number of e-products, $\mathrm{N}_{\mathrm{pc}}$ is the average per capita in the household sector, $\mathrm{P}$ represents the urban population, and $\mathrm{N}_{\mathrm{ei}}$ is the total number of the eproducts in the institutional sector (Table 4).

According to the collected data, there were $50 \mathrm{CD} / \mathrm{DVD}$, one cell phone, and one multimedia player per capita in the selected cities. Additionally, there was one automobile, one CRT television, and one camera per every four people. An Iranian government survey in 2012 estimated the number of automobiles to be 16 million, which is similar to the estimates in the present study and confirms its reliability [24]. The average number of the members per urban household was 3.6 in 2010 [25]. The household sector had an estimated 2.5 billion CD/DVDs, 250 million non-rechargeable batteries, 25 million landline phones, and 18 million personal and laptop computers. PCs were the most frequently used e-products in the institutional sector ( 24 million), followed by landline telephones (almost 20 million). The total number of the eproducts in this sector was calculated to be 92 million.

Two-way analysis of variance (ANOVA), Kruskal-Wallis test, and post-hoc tests were used to investigate the impact of economic changes on the purchase and consumption rates in various income zones. The results of ANOVA and KruskalWallis test indicated no statistically significant difference between the income zones in terms of the number of fax machines, CD/DVDs, game consoles, non-rechargeable batteries, radio sets, and CRT televisions, while there were 
significant differences between the zones in terms of the other e-products.

Improved economic health of urban families has increased the amount of e-waste, while inexpensive products (e.g., CD/DVDs) do not depend on wealth. All the income zones in the current research consumed large amounts of these products. In high-income zones, $18 \%$ of the population owning cell phones, $24 \%$ owning PCs, and $53 \%$ owning CRT televisions purchased a new unit regardless of whether or not their existing unit was obsolete, broken or repairable.

Table 3: Quantity of e-waste and e-part waste ready for EOL management in Iran

\begin{tabular}{lcc}
\hline E-product & E-waste & E-part waste \\
\hline Fax machine & 456,227 & $1,541,260$ \\
Landline phone & $6,430,047$ & $18,458,063$ \\
Cell phone & $9,617,559$ & $22,546,923$ \\
Printer & $1,347,494$ & $4,887,826$ \\
Scanner & 621,617 & $1,134,824$ \\
Photocopier & 201,770 & 913,369 \\
Laptop & $2,159,406$ & $5,359,811$ \\
PC & $2,354,948$ & $14,438,483$ \\
Flat screen monitor & $2,210,328$ & $2,798,242$ \\
CRT monitor & $1,060,481$ & $1,816,387$ \\
Multimedia player & $7,102,940$ & $21,856,445$ \\
CRT TV & 627,941 & $6,523,444$ \\
Flat screen TV & $2,061,823$ & $5,177,499$ \\
CD/DVD & $249,108,609$ & 0 \\
Camera & $2,205,369$ & $6,015,601$ \\
Other EE & $4,608,886$ & $12,985,511$ \\
Game Console & 664,415 & $1,769,571$ \\
Projector & 18,554 & 119,574 \\
Rechargeable & $6,903,386$ & 0 \\
battery & & 0 \\
Non-rechargeable & $50,697,473$ & 0 \\
battery & & 0 \\
Car battery & $2,400,194$ & 0 \\
Radio & 474,827 & 0 \\
Keyboard & $6,635,045$ & $0,342,833$ \\
Mouse & $6,635,045$ & \\
\hline Total & & 04,383 \\
\hline
\end{tabular}

Table 4: Weight of e-waste components (ton) in Iran

\begin{tabular}{lcc}
\hline Material & e-waste\% & e-waste components \\
\cline { 2 - 3 } Metal Iron & components & weight (ton) \\
Aluminum & 36 & $103,683.8$ \\
Copper & 5 & $14,400.5$ \\
Lead & 4 & $11,520.4$ \\
Cadmium & 0.29 & 835.2 \\
Mercury & 0.018 & 51.8 \\
Gold & 0.00007 & 0.2 \\
Silver & 0.00024 & 0.7 \\
Palladium & 0.0012 & 3.5 \\
Indium & 0.00006 & 0.2 \\
BFR plastics & 0.0005 & 1.4 \\
Plastics & 18 & $51,841.9$ \\
Lead glass & 12 & $34,561.3$ \\
Glass & 19 & $54,722.0$ \\
Other & 0.3 & 864.0 \\
\hline Total & 5.7 & $16,416.6$ \\
\hline
\end{tabular}

The results of the post-hoc test demonstrated that the similarities in income health between high- and middleincome families were associated with no significant differences in the purchases by the members of these zones.
On the other hand, significant differences were observed in the purchases between high- and low-income families due to the differences in their economic status.

\subsection{Estimation of Sales Data}

The import data are shown as combined categories, which do not allow the development of the totals based on the product type. In addition, there were no data on official sales in the country. To better account for e-product consumption, data on sales were collected using the questionnaires for eproduct retailers and wholesalers. Sales were estimated by calculating the 'apparent consumption', which represents the products that are sold in Iran for use within the country.

Apparent consumption was calculated for sellers since the lack of data on the number of the e-products sold in each city made it impossible to predict the sales data. Alternatively, the average number of the existing e-products in each city was calculated using the following formula:

$\overline{\mathrm{N}}_{\mathrm{ec}}=1.5\left(\mathrm{~N}_{\mathrm{i}}+\mathrm{N}_{\mathrm{h}}\right)$

Where, $\overline{\mathrm{N}}_{\mathrm{ec}}$ is the average number of e-products in each city, $\mathrm{Ni}$ is the total number of e-products in the institutional sector and $\mathrm{N}_{\mathrm{h}}$ is the total number of e-products in the household sector. It was assumed that the average number of e-products in a city comprised the units consumed plus at least half of that amount that is stored for future sale. This assumption is the reason for the constant coefficient (1.5) used in Equation 3.

The data for the sale of inventory are in agreement with the consumption data from Table 4 and indicates the reliability of the calculations. For example, in both tables, the highest number of units is for CD/DVDs and the lowest number of units is for projectors. In the institutional sector, about 92 million e-products existed and, in the household sector, over 3 billion e-products existed. The total number of e-products available for sale is about 5 billion units. In practice, the eproducts in stock outnumber the quantity in use and contribute to the increase in the rate of e-waste in the country.

\subsection{Quantity of E-waste}

Equation 4 combines the repair and consumption rates for each e-product, applying the lifespan assumptions to predict the number of the e-products still in storage that would eventually require EOL management. The equation was as follows:

$\mathrm{N}_{\mathrm{ew}}=\mathrm{N}_{\mathrm{re}}+\mathrm{N}_{\mathrm{ne}}$

Where $\mathrm{N}_{\mathrm{ew}}$ is the number of the e-waste units, $\mathrm{N}_{\mathrm{re}}$ represents the number of the repaired e-products by repair life, and $\mathrm{N}_{\text {ne }}$ denotes the number of the non-repaired e-products by lifespan. Repair life is the lifespan of a repaired unit, which is estimated to be 1.5 times that of a non-repaired unit.

Equation 5 was used to calculate the average number of the electronic parts (e-parts) in the waste, as follows:

$\mathrm{N}_{\text {ewp }}=\left(\mathrm{P}_{\mathrm{r}} \times \mathrm{N}_{\mathrm{re}}\right) / 100$ 
Where $\mathrm{N}_{\text {epw }}$ is the number of e-parts, $\mathrm{P}_{\mathrm{r}}$ is the percentage of replacement parts and $\mathrm{N}_{\mathrm{re}}$ is the number of repaired eproducts. The results are presented in Table 3 .

According to the current research, the number of the obsolete CRT monitors and televisions increased due to their limited future use, which is associated with a remarkable potential for the recycling of these items. Approximately $70 \%$ of the total e-waste units was observed in CD/DVDs, while non-rechargeable batteries constituted $14 \%$. To better account for the remaining e-waste, these items were eliminated from the distribution of e-waste. Cellular phones accounted for the highest percentage of the remaining units (about 10 million of the total 356 million units), followed by multimedia players, rechargeable batteries, landline telephones, mouse devices, and keyboards. This finding allows the prioritization of these products for recycling.

\subsection{Average Weight of E-waste}

In the present study, e-products were classified into seven categories (with the exception of CD/DVDs and batteries) in accordance with the EU methodology for weight based on the materials contained in each product [26]. The determined categories were as follows:

- ICT equipment, including PCs (CPUs, mouse devices, and keyboards), laptop computers, landline, cordless and cellular telephones, fax machines, printers, scanners, projectors, and copy equipment, had an average weight of 4.19 kilograms.

- CRT monitors had an average weight of 14.65 kilograms.

- Flat screen monitors had an average weight of 5.08 kilograms.

- Consumer electronic equipment, including radios, multimedia players, and audio and video cameras, had an average weight of 4.06 kilograms.

- CRT televisions had an average weight of 26.67 kilograms.

- Flat screen televisions (LCD/LED/plasma) had an average weight of 28.30 kilograms.

- Toys and leisure and sports equipment, including game consoles and other electronic equipment, had an average weight of 12.94 kilograms.

The average weight of e-waste was calculated by multiplying the quantity of e-waste in each group (Table 3 ) by the average weights of each item. The results shows that the total annual weight of the e-waste was estimated 288,000 tons. This is corresponding to $5.37 \mathrm{~kg}$ per capita, which is lower than the annual global estimate of $7.2 \mathrm{~kg}$ [7].

The average weight of e-waste components was calculated as the percentage of e-waste components as [27]:
$\mathrm{M}_{\mathrm{c}}=\frac{\mathrm{P}_{\mathrm{c}} \times \mathrm{M}_{\mathrm{W}}}{100}$

Where $\mathrm{M}_{\mathrm{c}}$ is the weight of e-waste components, $\mathrm{P}_{\mathrm{c}}$ is the percentage of e-waste components and $\mathrm{M}_{\mathrm{w}}$ is the total weight of the e-waste. The results are shown in Table 4 and show which components are the most profitable for recycling and those with the greatest impact on the environment. It is noteworthy that the lethal dose of mercury is $200 \mathrm{mg}$, meaning that the amount of mercury in e-waste in Iran is enough to kill that the amount of mercury in e-waste in Iran is enough to kill 1 million people.

\subsection{Prediction of E-waste}

Predicting the generation of e-waste is associated with several problems. The current techniques for this purpose are based on the typical product lifespan, market saturation factors, linear extrapolation, trend analysis, periodic approaches and their combinations. The techniques used to estimate future WEEE have been reviewed by Walk [28].

However, the limited data available in the present study prompted the use of economic growth estimations and gross domestic product (GDP), new purchases per capita, and population growth rate in households and institutions.

The population growth rate in subsequent years followed a linear correlation between the current growth and the predicted rate in $2050(0.8 \%)$. GDP grew at a fixed annual rate of $3.8 \%$ to 2050 [29]. The average rate for GDP growth from 2012 was $2.3 \%$ GDP per capita per year, which was calculated as a function of GDP and population growth $3.0 \%$ per capita). In the household sector, e-waste was predicted based on the predictions of the weight of e-waste, GDP per capita, and population (Figure 1).

According to the obtained estimates, e-waste across Iran is predicted to be approximately 10 million tons per year. Furthermore, the predictive techniques suggested that by 2032, the annual household e-waste could total 444 million tons. In the institutional sector, e-waste was calculated based on the number of the new purchases per capita and generated e-waste at a fixed rate.

As id depicted in Figure 2, there was a linear correlation between new purchases and the e-waste generated by institutions by 2022. New purchases are predicted to gradually increase to 3-5 million units, and e-waste generation has been predicted to increase from 500,000 to two million units per year. The remaining options in the absence of active disposal policies are disposal either in a landfill or by incineration. This scenario is the first development stage of ewaste management, which is unfortunately the current state in Iran.

The actual amount of e-waste is presumed to be greater than the estimated amount since small businesses and shops were not considered in the current investigation. People tend to replace televisions, monitors, and cell phones frequently to keep up with the latest technology. CRT televisions are outdated, and the urban population avoids their purchase. 
Consequently, there will be a shift to recycling flat screen technology in the near future. PCs outnumber laptops in household and institutional sectors, while the sales patterns in these sectors have reversed toward the purchase of laptops.
E-products such as CD/DVDs and batteries cannot be repaired. On the other hand, projectors, PCs, photocopiers, landline telephones, CRT televisions, game consoles, printers, fax machines, and laptops have a repair potential of $80-98 \%$.

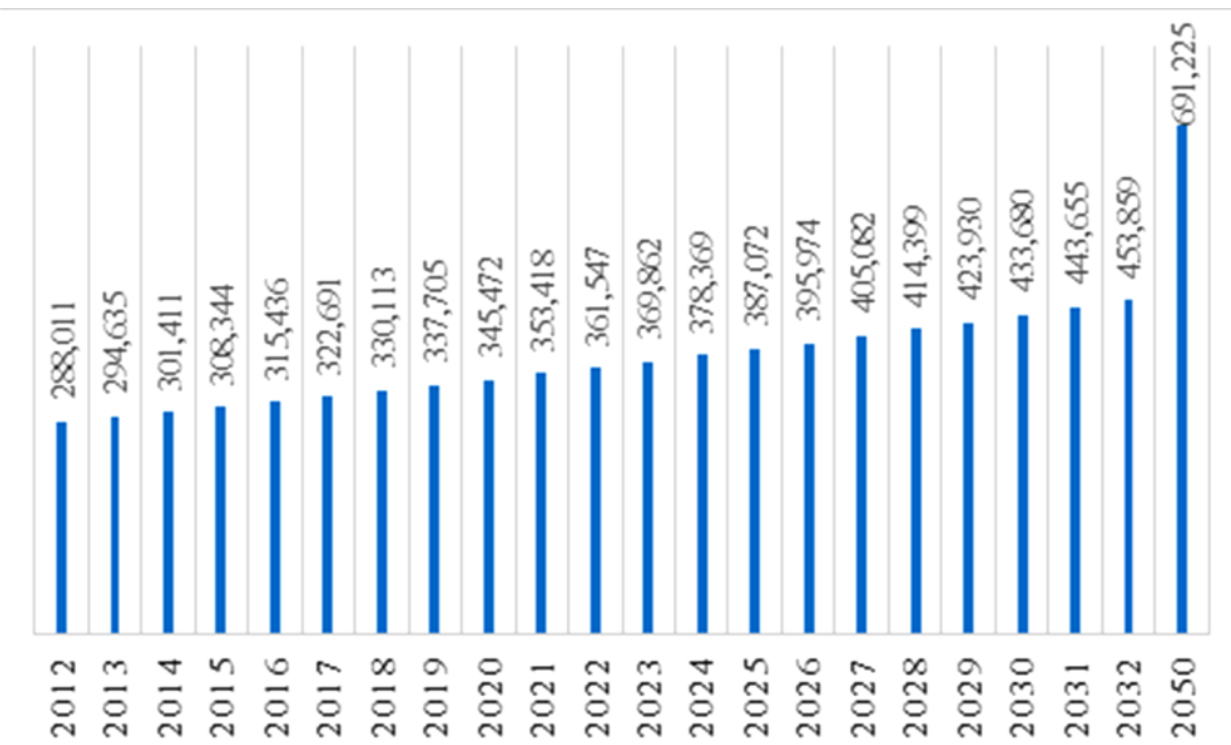

Figure 1: Forecasting e-waste weight (in Ton) in households sector in Iran

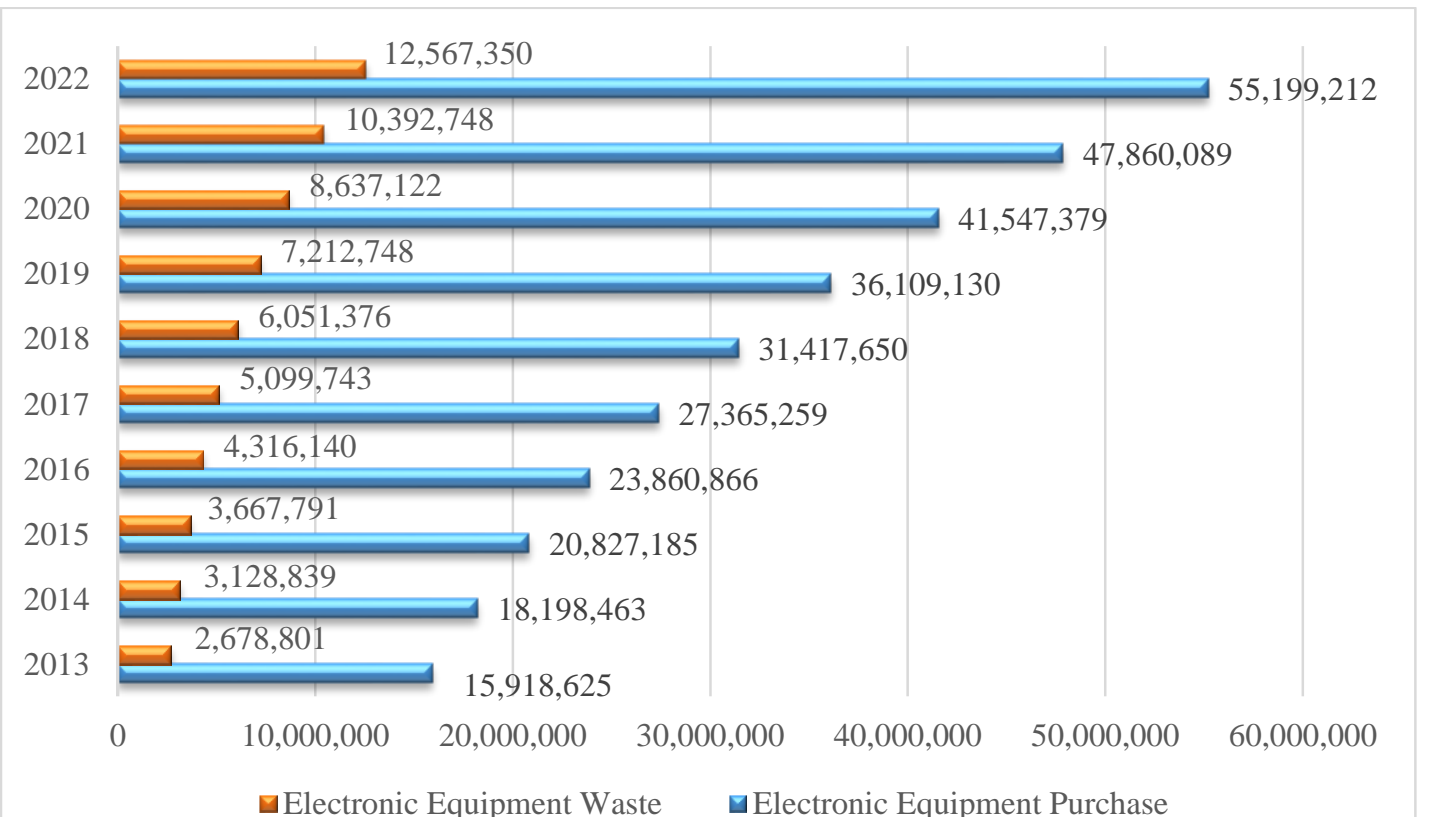

Figure 2: Relationship between the number of future purchases of e-products and e-wastes in institutional sector in Iran from 2013 to 2022

With the exception of scanners, $75 \%$ of all e-products in the present study could be repaired, which is a large percentage, prolonging the lifespan of these products. The highest replacement potential belonged to projectors, flat screen televisions and monitors, photocopiers, printers, multimedia players, fax machines, CRT televisions, and cellular phones. As the repair costs of these products have increased recently, people tend to purchase new e-products rather than repair them.
Usage patterns vary over time and are mainly based on the changes in purchasing behaviors and technology, which gradually increase the amount of e-waste. Estimates of the quantity and weight of e-waste should not be equated with the actual amounts that could be collected with the help of a proper collection infrastructure. The EOL estimations represent the theoretically available options for the collection of e-waste, which is currently stockpiled in all the sectors of economy. 


\section{Conclusion}

The national law on electrical and electronic waste management comprises 63 articles and was passed in 2010, while it has not been implemented yet. This law stipulates that e-waste contains hazardous materials, and effective e-waste management must be undertaken in order to decrease environmental pollutions and prevent the adverse effects on human health. As e-products, usage patterns, environmental awareness, and management options change over time, the purchase, storage, and EOL disposal will change in parallel. Although it is not certain that the results of the present study are representative of the entire Iranian nation, they provide a large dataset to be used as a starting point for the policy assessment in this regard.

The enactment of legislation to dispose of e-waste has been slow or non-existent in Iran. The stockpiling of e-waste is considered the norm in the cities across our country. This issue may give rise to numerous problems if the amount of ewaste reaches critical levels with no management policies. The optimal management practices in this respect involve guidelines for selecting the most environmentally desired methods to manage the e-waste stream, which encourage the reduction, reuse, manufacturing, recycling, and recovery of energy through incineration, as well as using landfills for residuals as the last resort. In addition, a limited informal material recovery effort could currently prevent valuable resources from re-entering the material cycle.

The generation of e-waste is a continuous and rapid process, which requires immediate action by the government. It is of paramount importance to raise the awareness of the community regarding the consequences of the improper disposal of hazardous waste.

\section{Authors' Contributions}

P.A.H., designed the interviews forms for all sectors with M.S.M., collaboration and conducted the interview. M.S.M., did interviews, analyzed data and wrote the manuscript. Y.M.R., conducted the study and revised the manuscript. Z.A.A., helped and analyzed the statistical data. All authors revised and approved the final manuscript.

\section{Conflict of Interest}

No conflict of interest declared.

\section{Acknowledgments}

This work was financially supported by University of Zanjan through the thesis titled: "Investigation on Electronic Waste Status in Iran". The authors specially thank Miss Majedi and Pak-Tinat for helping to fill out the interview forms of Sanandaj city, also Mr. Karami and Shadi Mirgerami to help out to fill the interview forms in Mashhad city and Zohre Mirgerami in Tehran.

\section{References}

1. Li J, Tian B, Liu T, Lio H, Wen X, Honda S. Status quo of E-waste Management in Mainland China. J Mater Cycles Waste Manag. 2006; 8: 13-20.

2. Electronic Product Recovery and Recycling Baseline Report: Recycling of Selected Electronic Products in the United States. NS Council: Washington DC; 1999.

3. Widmer R, Oswald-Krapf H, Sinha-Khetriwal D, Schnellmann M, Böni H. Global Perspectives on E-waste. Environ Impact Assess Rev. 2005; 25: 436-58.

4. European Union Directive 2002/96/EC of the European Parliament and of the Council of 27 January 2003 on Waste Electrical and Electronic Equipment (WEEE). Brussels: Office for Official Publications of the European Communities; 2002.

5. Puckett J, Byster L, Westervelt S, Gutierrez R, Davis S, Hussain A, Dutta M. Exporting Harm: The High-Tech Trashing of Asia. The Basel Action Network (BAN), Silicon Valley Toxics Coalition (SVTC). 2003. Available from: URL:http://www.ban.org/Ewaste/technotrashfinalcomp.pdf. Accessed 20/11/ 2012.

6. Electronics Product Stewardship Canada (EPS): Environmentally Sound Recycling of Electronics, Guidance Document. 2006. Available from: URL: http://www.epsc.ca/EPS. Accessed 20/11/ 2012.

7. Ongondo FO, Williams ID, Cherrett TJ. How are WEEE doing? A Global Review of the Management of Electrical and Electronic Wastes. Waste Manag. 2011; 31 (4): 714-30

8. Cui J, Forssberg E. Mechanical Recycling of Waste Electric and Electronic Equipment: A Review. J Hazard Mater. 2003; 99 (3): 243-63.

9. Bains N, Goosey M, Holloway L, Shayler M. An Integrated Approach to Electronic Waste (WEEE) Recycling: Socio-Economic Analysis Report. Rohm and Haas Electronic Materials Ltd., UK; 2006.

10. Bohr P. The Economics of Electronics Recycling: New Approaches to Extended Producer Responsibility. PhD Dissertation: Technische Universität Berlin, Germany; 2007.

11. The Natural Edge Project (NEP). E-Waste Curriculum Development Project. Phase 1: Literature Review. The Natural Edge Project (NEP). 2006. Available from: URL: http://www.naturaledgeproject.net/default.aspx. Accessed 20/11/ 2012.

12. Greenpeace. The E-waste Problem. Greenpeace International. Available from: URL: http://www.greenpeace.org/ international/campaigns/toxics/electronics/the-e-waste-problem\#. Accessed 20/11/2012.

13. Savage M, Ogilvie S, Slezak J. Implementation of Waste Electric and Electronic Equipment Directive in EU 25. IPTS: European Commission Joint Research Centre: Technical Report Series EUR 22231 EN, ISBN 92-79-01926-0, Luxembourg; 2006.

14. Abdoli M, DaryabeighiZandA. Analysis of Computer Wastes. Ecol J. 2005; 37: 105-12.

15. AlaviBakhtiyarvand SN, Akhtar Danesh J, Takdastan A, Bagheri N, Fakheri F, Babae A. Electronic and Electric Wastes Management in Ahvaz, Symposium of Environmental Crisis and its Solutions, Kish Island, Iran. Sci Res Branch, Khouzestan, Islamic Azad Univ. 2013; 2902-8.

16. Zoeteman BCJ, Krikke HR, Venselaar J. Handling Electronic Waste Flows: on the Effectiveness of Producer Responsibility in a Globalizing World. Int J Adv Manuf Technol. 2010; 47(5-8): 41536 . 
17. World Bank. World Development Indicators. ISBN: 978-0-82138443-5; 2010.

18. Schluep M, Müller E, Ott D, Rochat D. E-waste Assessment Methodology Training \& Reference Manual. Swiss Federal Laboratories for Materials Science and Technology (Empa), Switzerland; 2012.

19. Directive 2012/19/EU of the European Parliament and of the Council of 4 July 2012 on Waste Electrical and Electronic Equipment, WEEE. J Eur Union L. 2012; 197: 38-71. Available from: URL: http://eurlex.europa.eu/LexUriServ/LexUriServ.do?uri=OJ:L:2012: 197:0038:0071:en:PDF. Accessed 20/11/ 2012.

20. United Nations Environmental Program (UNEP), E-waste Volume I: Inventory Assessment Manual. Compiled by United Nations Environmental Program, Division of Technology, Industry and Economics, International Environmental Technology Centre, Osaka/Shiga.http://www.unep.or.jp/ietc/Publications/spc/EWasteM anual_Voll.pdf. 2007.

21. Lohse J, Winteler S, Wulf-Schnabel J. Collection Targets for Waste from Electrical and Electronic Equipment (WEEE) the Directorate General (DG XI) Environment. Nuclear Safety and Civil Protection of the Commission of the European Communities. 1998.

22. Robinson BH. E-waste: An Assessment of Global Production and Environmental Impacts. Sci Total Environ. 2009; 408(2): 183-91.
23. Eugster M, Hischier R, Duan H. Key Environmental Impacts of the Chinese EEE-Industry: A Life Cycle Assessment Study, Final Report. EMPA, Mater Sci Technolo. 2007.

24. Statistical Center of Iran. 2010. Available from: URL: http://www.amar.org.ir. Accessed 20/11/ 2012.

25. Statistical Center of Iran. 2012. Available from: URL: http:// www.amar.org.ir. Accessed 20/11/ 2012.

26. UN Final Report. Review of Directive 2002/96 on Waste Electrical and Electronic Equipment- Study No. 07010401/2006/442493/ETU/G4.ENV.G.4/ETU/2006/0032. United Nations University, Bonn, Germany. 2007; 162-70.

27. European Topic Centre on Sustainable Consumption and Production (ETC/SCP). Available from: URL: http://scp.eionet.europa.eu/themes/waste. Accessed 20/11/2012.

28. Walk W. Approaches to Estimate Future Quantities of Waste Electrical and Electronic Equipment WEEE. Forschungszentrum Karlsruhe GmbH, InstitutfürTechnischeChemie, Karlsruhe. 2004.

29. Hawksworth J, Cookson G. The World in 2050 Beyond the BRICs: a Broader Look at Emerging Market Growth Prospects. PricewaterhouseCoopers LLP. England. 2008. Available from: URL:http://www.pwc.ch/user_content/editor/files/publ_tls/pwc_the _world_in_2050_e.pdf. Accessed 20/11/ 2012. 